\title{
A case study on service recovery: Frontline employees' perspectives and the role of empowerment
}

DOI 10.1515/ejthr-2016-0014

received 30 June, 2015; accepted 20 July, 2015

\begin{abstract}
The aim of this study was to improve our understanding of how frontline employees cope with service recovery situations and recover from them. It also takes a closer look at employee empowerment. This work represents a qualitative case study, and investigates the topic from the perspective of frontline employees. Data collection is implemented by interviewing the case hotel's frontline personnel. A content analysis method was utilised to analyse the collected data. The findings suggest that the support of colleagues is more crucial in coping with service recovery situations and recovering from them than the support of managers. Personality traits also play a role. A theoretical scheme of the service recovery process from the perspective of frontline employees is developed from the analysis of the interviews. The findings indicate that written instructions would assist employees in service recovery situations.
\end{abstract}

Keywords: Service failure, Service recovery, Employee recovery, Empowerment, Frontline employee.

\section{Introduction}

Service recovery refers to all actions, which an organisation takes when it attempts to reconcile service failures (Grönroos, 1988; Black \& Kelley, 2009). The literature has mainly taken a marketing view of recovery (Johnston

\footnotetext{
*Corresponding author: Raija Komppula, University of Eastern Finland, Business School, P.O.Box 111, Fl-80101 Joensuu, Tel. +358 504387 475, Email: raija.komppula@uef.fi

Satu Schumacher, University of Eastern Finland, Business School, P.O.Box 111, FI-80101 Joensuu
}

\& Michel, 2008) and the impact on customer satisfaction and future purchase intentions has been the major concern (Black \& Kelley, 2009). Many research have shown that an adequate service recovery strategy can result in various positive outcomes (Smith \& Karwan, 2010; Wilson, Zeithaml, Bitner \& Gremler, 2008), such as improved perceived justice and increased value perceived by customers (Chang \& Hsiao, 2008), creation of positive word-of-mouth communication (Swanson \& Kelley, 2001), increased post-failure levels of satisfaction and purchase intentions (Maxham III, 2001), and increased customer loyalty (Komunda \& Osarenkhoe, 2012).

Michel, Bowen and Johnston (2009) define service recovery as an integration of actions that the company takes 'to re-establish customer satisfaction and loyalty after a service failure (customer recovery), to ensure that failure incidents encourage learning and process improvement (process recovery) and to train and reward employees for this purpose (employee recovery)' (p. 267). Research on service recovery has mostly focused on the perspective of customers, referring to the external level of service recovery (Johnston \& Michel, 2008). Prior research has shown that complaining customers highly value apologies (Bradley \& Sparks, 2009) and the authenticity, competence and active listening skills of contact employees (Gruber, 2011). The study of McQuilken (2010) suggests that when employees show a high degree of effort in failure situations, evaluations of trust among customers are reinforced. Prior research has also indicated the effects of a company's recovery response to other-customer failure.

Recent studies in the field of hospitality have approached service recovery from several perspectives. Lee, Singh and Chan (2011) and Pranic and Roehl (2012) focused on the perspective of customer recovery. Lee et al. (2011) emphasise the importance of explaining and apologizing in the relationships with aggrieved customers. Pranic and Roehl (2012) state that the level of complainant's affective/cognitive responses and the level of subsequent complaint satisfaction are determined by how the complainant perceives empowerment during

(cc) BY-NC-ND 2016 Satu Schumacher, Raija Komppula published by De Gruyter Open

This work is licensed under the Creative Commons Attribution-NonCommercial-NoDerivs 3.0 License. 
service recovery. From the perspective of process recovery, the study of Lee et al. (2011) indicates that most of the service failures occur during guest arrival and departure and in the food and beverage services. According to their results, the most commonly implemented means of recovery were some form of compensation (e.g. discounts or room upgrades), prompt explanations of the situation to the customers and apologizing. The very few studies from the perspective of employee recovery in the hotel field have paid attention to how customer aggression affects the employees (Karatepe, Yorganci \& Haktanir, 2009) and factors that decrease (Kim, Yoo, Lee \& Kim, 2012; Karatepe et al., 2009) or increase (Karatepe, 2012; Kim et al., 2012) service recovery performance.

Johnston and Michel (2008) recognise the key role of frontline employees in the service recovery process, as they are usually the targets of customer complaints, but sometimes the employee may not even be authorised to solve the failure (Bowen and Johnston, 1999). Although the perspective of employees on the service recovery process is an important aspect, it has received surprisingly limited attention in research into service recovery (Suh, Barker, Pegg \& Kandampully, 2005). Additionally, to the best of our knowledge, except for the study of Bowen and Johnston (1999), all the other studies on employee recovery represent a quantitative research approach, lacking the voice of the employees. In earlier studies, the data are collected from employees of four and/or five star hotels (Karatepe et al. 2009; Kim et al. 2012), which are often large in size. Hence, in this study, a qualitative approach is applied, aiming to achieve further insights into the personnel's perceptions and feelings on service recovery. Additionally, our case study represents the most common type of business in the hospitality industry, namely a small privately owned hotel in a lower price bracket.

Frontline employees play a crucial role during both service delivery and service recovery (Boshoff \& Allen, 2000). They are the link between the company and customers, having an understanding of the constraints due to the company budget and being the closest observers of customers' demands. Therefore, frontline employees provide the best insight into the execution of service recovery processes in practice. Grönroos (2007) states that it is important that frontline employees are empowered, skilled and authorised to use the needed sources of information, the compensation system and support from supervisors if needed.

The objective of the study at hand is to increase our understanding of the frontline employees' perspective on service recovery and the role of employee empowerment from the viewpoint of the personnel. We present findings of an exploratory case study, in which the personnel of the hotel were interviewed to answer the main research question: How do frontline personnel perceive service recovery situations within the case hotel? The research process involved three sub questions, the first of them aiming to determine the current state of service recovery implementation at the hotel. Then, the level of management support and empowerment was studied. Finally, the last sub question was how frontline personnel cope with service recovery situations.

\section{Theory}

\subsection{Employee recovery}

The findings of Johnston and Michel (2008) show that service recovery procedures seem to have a greater impact on employees and process improvement than on the customers. Boshoff and Allen (2000) point out that service recovery can actually be a win-win-win situation for customers, frontline employees and the service company, as an effective service recovery can turn aggrieved customers into satisfied ones, help the employees enjoy their job more and allow the company to benefit from long-term customer relationships and decreasing costs. According to Michel, Bowen and Johnston (2009) implementing an effective service recovery, especially requires investment into long-term customer relationships, and employees' continuing development to deal with various failures.

The internal level of service recovery, which includes the perspective of an organisation and its employees, will be the main interest of this study. As Johnston and Michel (2008) did, we use the term employee recovery to define the internal perspective of service recovery. According to Bowen and Johnston (1999): 'internal service recovery refers to what the organisation does to make internal customers, that is, front-line employees, feel "whole" after external recovery episodes' (p. 119). The authors continue that internal service recovery focuses on recovering employees from the negative feelings that failure situations may cause and strengthening employees' confidence in the ability to satisfy customers in the future. Prior research has found a positive correlation between the employees' and customer's perceptions of how well they recovered, the employees internally and the customers, externally (Bowen \& Johnston, 1999; Yoo, Shin \& Yang, 2006). Cook (2002) indicates that the external customer 
is more likely to receive good service if the employee has received good service internally within the organisation.

Effective service recovery performance has been found to enhance job satisfaction of frontline employees (Yavas, Karatepe, Avci \& Tekinkus, 2003; Crawford and Riscinto-Kozub, 2010), while poor service recovery actions may frustrate the firm's best employees (Wilson, Zeithaml, Bitner, \& Gremler, 2008). Lovelock and Wirtz (2011) state that today's most successful service companies have understood the importance of investing in their staff and have committed to the efficient management of human resources (HR) in terms of recruitment, selection, training, motivation and retention of employees. However, research concerning how the personnel - mainly frontline employees - perceive service recovery actions have been scarce. To the best of our knowledge, there are only a few studies that have contributed to bridging this gap.

The findings of Bowen and Johnston (1999) indicate that, when dealing with failures, employees often confront feelings of low perceived control and helplessness. The authors suggest that the management should have similar internal service recovery obligations to fulfill as employees have in external service recoveries. Yoo et al. (2006) found that the most appealing service recovery strategies perceived by frontline employees include pay rises, recognition from colleagues, a case-by-case reward method and full empowerment. The authors claim that it is probable that the recovery efforts stress employees less if they sense more support. Yoo et al. (2006) also suggest that service employees should be given both psychological and tangible rewards for their accomplishments in service recovery efforts.

Yavas, Karatepe and Babakus (2010) investigated the relative efficacies of organisational support mechanisms and personality traits in predicting frontline employees' service recovery and job performances. Their findings suggest that regarding service recovery performance organisational support is more efficient when one differentiates between high- and low-performing frontline employees. Karatepe et al. (2009) found the emotional dissonance and emotional exhaustion among hotel employees to be significant outcomes of customer verbal aggression. Recent studies have also found that emotional exhaustion (Karatepe et al., 2009) and surface acting (Kim et al., 2012), referring to faking the expected emotions, decreased service recovery performance. To the contrary, frontline hotel employee emotional intelligence and genuine attempts to experience positive emotions (Kim et al. 2012), as well as perceived organisational support (Karatepe, 2012), have been found to relate positively and increase the service recovery performance. The findings of the study of Karatepe (2012) also suggest that job embeddedness, referring to the factors that contribute to employees' staying at a company, has a moderating role on the relationship between perceived organisational support and service recovery performance. Karatepe (2012) claims that employees who are highly embedded would not require coworker support to improve the levels of their service recovery performance.

\subsection{The role of empowerment in service recovery}

Empowerment plays an important role in service recovery (Cook 2002), and it has been found to have a positive relationship with service recovery performance (Yavas et al., 2003; Crawford \& Riscinto-Kozub, 2010; Yavas et al. 2010). Empowerment has been used for explaining organisational effectiveness, and is derived from the constructs of power and control (Conger \& Kanungo, 1988). Definitions of empowerment refer to the actions of the employer in ensuring the employees have the skills and knowledge to be able to resolve complaints (Cook, 2002), as well as being able to make decisions and find solutions in order to customise the service delivery (Lovelock \& Wirtz, 2011). Bradley and Sparks (2000) view empowerment as 'a means of placing decision making lower in the organisation, thereby releasing resources that otherwise may have been underutilized' (p. 992).

Cook (2002) divides empowerment into three levels. On the third level, which refers to the term full empowerment introduced by Yoo et al. (2006), the employees can take overall control of the decisions concerning their work and working patterns (Cook, 2002). It enables the employee who hears the customer's version of the mishap to be in charge of deciding how to resolve it (Bradley \& Sparks, 2000). On the second level, employees are authorised to make decisions concerning their work but they are left out of the strategic decision-making process. Yoo et al. (2006) in turn use the term partial empowerment, meaning that employees have to be authorised by their supervisor before solving the failure. Cook's (2002) first level of empowerment means that the manager has the overall authority, even though employees are encouraged to make their own decisions and participate in improvement initiatives. Bradley and Sparks (2000) talk about a level of non-empowerment, in which a supervisor handles all the customer complaints.

Empowerment helps the employees to deal with mishaps quickly and more efficiently (Boshoff \& Allen, 2000; Yavas et al., 2010), and helps them better to manage 
aggrieved customers (Karatepe et al., 2009). Prior research has shown that customers appreciate dealing with fully empowered employees (Boshoff \& Leong, 1998; Bradley \& Sparks, 2000) and highly value when employees break the rules to respond faster to a specific service need (Suh et al., 2005). Suh et al. (2005) indicate that the company's empowerment and recovery strategies 'encourage service employees to adopt initiatives to go beyond their call of duty, and to recover from service mishaps, while gaining important failure-related information to prevent future mishaps' (p. 49). As the authors note, it is possible to commence service recovery before, during or after the service failure happens (Suh et al., 2005).

Full empowerment has also been found to increase employees' pride and motivation at work, give people feelings of self-worth (Firnstahl, 1989), and employees can perceive empowerment as a sign of trust from the management (Karatepe et al., 2009). Pelit, Öztürk and Arslantürk (2011) suggest that employee empowerment can be used indirectly to decrease employee turnover, while Yagil (2009) indicates that there is a negative relationship between empowerment and burnout.

In order to gain the benefits of employee empowerment, the company should involve empowerment in its entire culture and strategy (Boshoff \& Allen, 2000; Cook, 2002). Suh et al. (2005) argue that empowerment issues in companies are too often handled on a day-to-day operational level rather than on a strategic decision-making level. The empowerment of staff may lead to a significant incline in costs (Bradley \& Sparks, 2000), because, according to Ro and Chen (2011), adequate organisational supporting systems, including service training, service rewards, and service standards communication, are needed for increasing employee empowerment. On the other hand, the initial investment in training may pay for itself many times over, if the problems can be solved with less effort and the quality of customer response can be improved (Cook, 2002).

Ro and Chen (2011) suggest that the employees' customer orientation characteristics should be considered to implement an efficient empowerment program. Their results suggest the more employees described themselves as customer oriented, the more confident they felt about their job performance and the more meaningful they regarded their job to be. Yagil (2002), in turn, states that a service employee having a sense of control over the situation is inclined to act independently and needs less advice from the supervisor compared to an employee with a low sense of control. The author indicates that the employee's sense of control and the supervisor's empowering behaviour are likely to be related to each other as a result of a recurrent enhancement process.

The critical point in evaluating a company's level of empowerment is to pay attention to the managerial response to how employees utilise their empowerment. The management's reaction to a mistake made by an employee reveals how committed to empowering the company really is (Boshoff \& Allen, 2000). It is important that each frontline employee is aware of the degree he/she can deal with failures. It reduces confusion and increases employees' confidence in solving failures in the best manner (Yavas et al., 2003; Yavas et al., 2010). Hence, it is essential that managers discuss with the employees the content and goals of the empowerment actions (Pelit et al., 2011). Karatepe et al. (2009) highlight that the demands of the job should be in line with employees' abilities.

It is notable that not all employees desire to be empowered, some prefer to have some directions (Cook, 2002; Lovelock \& Wirtz, 2011). The findings of a recent study indicate that employees usually desire some empowerment in the form of control, authority and decision making, but the level and form of the preferred empowerment varies between individuals (Greasley, Bryman, Dainty, Price, Naismith \& Soetanto, 2008). This study aims to find out how the frontline employees at the case hotel perceive their empowerment in service recovery situations and whether they desire to be empowered or not.

As the literature review shows, the service recovery concept is a broad process and it can be examined from a variety of perspectives. Service failures occur when some aspect in the service delivery does not meet the customers' expectations (Lovelock \& Wirtz 2011). Frontline employees may either spot the service failures themselves or be informed about them by customers. Frontline employees and managers attempt to resolve service errors once they are aware of them. Frontline employees are mainly able to influence the process related failures while the management is responsible for failures that require more financial contributions, the renovation of rooms, for example. When service failures occur, customers show their dissatisfaction to frontline employees. Frontline employees then have to recover the service in order to ensure the customers are satisfied. The level to which the management empowers employees, determines to what extent the employees can resolve service failures. Managers determine the company policies, which determine the boundaries within which the employees can work. 


\section{Data and method}

An intrinsic, intensive case study strategy was chosen, as it enables us to reach an in-depth understanding of the phenomenon instead of a generalisation (Thomas, 2011). The case is a small, privately owned, full service hotel in a lower price bracket, located in the city centre of Helsinki, Finland, catering for both business travellers and tourists. The empirical data consist of semi-structured interviews, which were conducted among seven frontline employees working at the reception of the hotel. In addition, the frontline manager who acts as the nearest supervisor to the frontline employees, as well as the hotel manager, were interviewed to gain an insight into company policies concerning the service recovery and how the management supports and empowers the frontline employees to resolve service failures. The interviews took around an hour each. The group of interviewees includes six women and three men. The number of working years among the interviewees ranges from 1 year up to 20 years. Two of the interviewees were working part-time and seven full-time. The interviews were recorded and transcribed.

The analysis of data responding to the sub-questions one, 'How is service recovery currently implemented?', and two, 'How does the management support and empower the frontline in service recovery?', is theory-guided (Eriksson and Kovalainen, 2008). The data were analysed by content analysis, by repeatedly reading and organising the data and classifying or thematising it (Eriksson \& Kovalainen 2008). At this stage of the analysis, the factual matters were separated from the parts that included the perceptions of the frontline employees. Then, the process of thematic analysis followed, including organisation and categorisation of codes into thematic groupings (Roulston, 2010), after which interpretations and thematic representations were developed. This part of the study utilises abductive inference, which refers to making judgment concerning the best explanation for the facts one is collecting (Thomas 2011) both by considering the data and former knowledge of the subject (Reichertz 2004).

In order to deepen the understanding of the frontline employees' perceptions of service recovery processes, a data-driven analysis for the third sub-question, 'How do the frontline personnel cope with service recovery situations?', followed. The main interest is therefore to find interesting codes, referring to the content-related matters that exist in the data (Eriksson \& Kovalainen, 2008). Coding helps discard repetitious and unnecessary information and increases the clarity of the text (Ohnesorge, 2004). The data-driven approach enables the researcher to find important factors in frontline employees' perceptions without presuming the factors from theory. In the presentation of our findings, HM stands for hotel manager and FM for frontline manager, while F1 to F7 refer to the frontline employees.

\section{Findings}

\subsection{Current implementation of service recovery and empowerment at the case hotel}

The case hotel relies mainly on customer feedback concerning service failures. It is not a normal procedure that frontline employees would ask the customers how their stay has been at the hotel. Instead, the customers are asked to fill in the feedback form if they provide oral feedback. The frontline manager states: 'In particular if (the feedback) is negative, we usually ask (the customers) to fill in the feedback form because it is valued differently when it is written by a customer than if it is forwarded by us', (FM).

According to the frontline manager, the frontline employees usually resolve the service failures themselves. Only when it comes to significantly large failures or when large amounts of compensation are required, the hotel manager will be included in the resolution. Sometimes customers may, for instance, consider service failures so serious that they want to cancel all of their future reservations at the hotel. According to the hotel manager, in these kinds of rarely occurring situations he contacts the customer promptly. The frontline manager indicates that sometimes customers also want to talk specifically to the hotel manager. 'It is a fact that for many people the point that a hotel manager will be in touch contributes to resolving the matter because it may reflect to (the customers) that they have been taken seriously', (F7).

Monetary compensation is considered to be the easiest and most satisfactory method among customers at the case hotel (FM). There is no certain amount determined that would be adequate in compensation of the room rates. Other compensation methods used include gift vouchers, free use of sauna, free of charge amenities in the room or non-alcoholic beverages or food. The interviewees indicated that they usually attempt to find the least expensive compensation method and aim at giving compensation for something else rather than the room rate. When service failures concern the quality of the hotel rooms, the interviewees indicated consistently that the 
easiest thing to do is to change the room for a better one, if possible. The interviewees all agreed that apologising is important in service recovery situations, even though frontline employees may not be responsible for the service failure.

The frontline manager found it important to remain humble and calm when dealing with aggrieved customers. Another interviewee thought that one of the most important goals in service recovery situations is to make the customers feel that they are acknowledged and cared about. Tranquility and kindness were also found to be effective when resolving service failures with annoyed customers: 'A friendly attitude and not going along with the customers' anger', (F2).

\subsection{Management support and empowerment}

The failures that occur at the hotel are resolved by using common sense and according to the hotel manager this has been applied successfully. 'We don't have any kind of guidebook on how to act in different situations and all goes according to feeling', (FM). It was considered challenging among the interviewees to have instructions on how to resolve service failures: 'It would be very difficult to collect a manual because there are so many things that customers may comment about', (HM).

The new employees learn from the more experienced employees how to resolve situations. 'Not all situations occur (during orientation) and when they occur later they may be handled inconsistently', (F5). The comment refers to the point that each frontline employee may have their own method of dealing with problem situations: 'There are (frontline employees) who have been in the house for 20 years and they handle things in their ways. Then some (frontline employees) have been (at the hotel) for two years or less so the scale is quite wide', (F7).

The interviewees agreed that it is important to resolve the failures as quickly as possible. Usually, the frontline employees try to solve the matters first by themselves. As an interviewee indicates: 'We have been given quite a free hand for authority and compensation related issues, of course within some limits', (F5). The hotel manager also indicated that he is confident of the frontline employees' ability to resolve service failures. 'No one who is working on our reception has to call someone to ask for permission whether he/she can give some discount', (FM). One interviewee (F5) considers this as a sign of trust: 'They trust us and we can make the decisions ourselves', (F5). Even though the frontline employees can make the decisions themselves, they appear to easily ask colleagues for their opinions. An interviewee pointed out that she feels slightly more insecure making decisions by herself when another colleague is standing next to her: 'I know I could make the decisions myself if I was alone in the shift, but I feel that (the colleague) knows better anyway and has been working longer and more' (F2).

Even though there is no set amount that would be officially determined as an adequate amount of compensation, the interviewees consistently suggested that the frontline employees are reluctant to provide discounts higher than $10-20 \%$ of the room rates. Nevertheless, there are some tools for compensation, which the frontline employees are not authorised to utilise. 'We don't write gift vouchers (at the reception) but I don't know if I would even like to do it', (F5). According to the hotel manager, the frontline personnel's authority also excludes providing alcoholic beverages to customers. Sometimes frontline employees feel that they would like to use certain compensation methods but think that it would contradict the company's common practices. 'I always think (in service recovery situations) right away what I should do according to the hotel's practice instead of what I would do myself. And they do sometimes contradict each other", (F2).

Failure situations are normally discussed among the frontline employees, but no general meetings about service recovery situations organised by managers are held. Each shift advises the new shift of all important and unusual matters. However, the frontline manager states: 'If an employee feels that he/she would need some advice for the future, or would like to open up, so then of course we can go through things (service recovery situations)', (FM). The hotel manager agrees and stated that sometimes the frontline employees may feel the need to discuss some difficult cases for a long time. Some of the interviewees thought that organizing meetings to discuss service failure situations might exaggerate the situation, others would find meetings beneficial because they 'would provide hints on how to work because people may have totally different views on things', (F6).

\subsection{Frontline employees' perceptions of service recovery situations}

\subsubsection{Recovering from aggrieved customers}

In general, the interviewees consistently appreciate customer feedback. According to the interviewees, most of the customers calmly inform what is wrong and are willing to solve the problem with the help of frontline employees. In these cases, resolving the failures can be considered a 
pleasant part of the job. Frontline employees found it particularly annoying, however when some customers come to the reception to shout loudly and do not pay any attention to the fact that there are other customers present as well. The hotel manager was aware of the harm that the service recovery situations may cause to frontline employees: 'In the worst case it ruins employees' working shifts for the following couple of days because the customer is still at the hotel at least on the following day and every time you see her/him, it reminds you of it'. On the other hand, one of the interviewees states: 'Then of course, if it (dealing with an annoyed customer) happens in the morning, I try even harder to show the customer that they are not going to walk all over me', (F7).

The interviewees indicate that it is essential to be empathetic towards customers while resolving service failures. Many interviewees also understand that customers' negative behaviours can just come to a head at the reception after many other inconvenient coincidences:

'Customers may have had an exhausting flight, they may suffer from jetlag, their luggage may have been lost or everything else may have gone wrong before arriving at the hotel and then they get angry even about a smaller thing'. (F4)

Nevertheless, the employee's own mood may have an influence on how they perceive the situation and if they can display any empathy towards aggrieved customers: 'If you feel fine, it doesn't usually bother me and I don't take the situations so personally. But if you happen to have a bad day, then it might bother you more' (F2).

The personal characteristics of frontline employees also influence how easily they are able to forget about dealing with angry customers. For some frontline employees angry customers may stay in mind for several days, while another interviewee said that he may think about angry customers, 'until the working shift is over but I don't think about them at home anymore. Nowadays I can leave them at the workplace'. (F6). One interviewee found it important to resolve the situations to oneself rationally as he states: 'You just have to think that could you have done something differently so that the customer would have been more satisfied and usually, anyway, you have tried to think of the best solution', (F6). Dealing with angry customers may become easier over the working years and one learns to not take it so seriously.

The type of failure also affected how dealing with aggrieved customers was perceived. Occasionally, frontline employees found it frustrating when customers complain about the same things which cannot be fixed: 'Some failures are such serious structural problems that you can't fix them and it's the most unfortunate thing of all when customers complain about the same room, or same thing', (F1). On the other hand, some frontline employees indicated that they can get used to the often-repetitive complaints. If frontline employees have caused the failure themselves, they could perceive handling angry customers more personally and therefore, the whole situation may feel more unpleasant and difficult to overcome: 'If you have done something wrong yourself, what remains bothering me is ...that I could have done something better', (F4). Or as another frontline employee indicated: 'I don't think anything else would stay in my mind except for if a customer would personally insult me. I try not to take it personally when a customer complains about rooms, for example', (F5).

Going through the difficult situations with colleagues appeared to be very important for many interviewees for overcoming these situations:

\begin{abstract}
'Angry customers don't usually stay in mind so long because we go over the situations quite well with the colleague you are working with. We talk about the situation and may agree that the customer really wasn't right and think whether I was wrong or what actually happened'. (F3)
\end{abstract}

\subsubsection{Level of empowerment}

It was not clear to the employees to what extent they are authorised to resolve service failures. Many of the frontline employees considered it a good idea to have some written instructions on how to resolve service failures: 'It would sort of bring clarity if we would have instructions', (F2). One interviewee acknowledged that personal characteristics may influence the need for having instructions: 'Some people need more instructions than others. And I rather prefer to have some guidelines where it says how to work'. (F6).

The responses revealed that frontline employees consistently would like to have some kinds of instructions on to what extent it is adequate to resolve and compensate service failures. One frontline employee indicated that instructions may provide proof that it is fine to give compensation: 'If we had written instructions we would have in black and white that we can compensate $20 \%$, for example', (F7). Another interviewee (F6) specified that if, for instance, things have gone wrong, it is noisy in the room etc., there would be suggestive instructions on to what extent compensation can be given. One interviewee mentioned that customers may not be handled equally when there are no clear instructions: 
'Sometimes I feel that a colleague may have already promised a better room (to a customer) while I think that the customer wouldn't be entitled to it. For these situations instructions may be good so that you wouldn't have to feel insecure about whether everyone is working the same way' (F3).

The responses also indicated that, for instance, the amounts that frontline employees choose to compensate the customers do not necessarily follow a consistent line. Some interviewees found it problematic to create instructions, as the situations are always unique: 'Then of course, what is the case, and what if the case is this plus this?' (F7).

Many interviewees stated that they are satisfied with the authority they currently have. The responses indicate that frontline employees are truly willing to forward challenging cases to managers and would not even like to be empowered to resolve them: 'Now it feels like a good middle way. I can (resolve) small kinds of matters. The bigger cases really occur so rarely', (F7). Another interviewee connected authority to the position of the manager and indicated: 'I don't need authority. I don't need a supervisor status. It is not my thing', (F1). According to one interviewee, the most difficult decision was whether to give compensation or not:

'Basically the boundary whether only an apology would be enough or whether I should give compensation directly is huge. But when I have made the decision, then you can sense quite quickly from the customer whether the compensation is sufficient or not'. (F7)

According to the frontline manager, after the situations have been handled they are not further discussed: 'I can't go and say that you should have given 10 euros less (discount) or so...if the resolution goes well, it's fine so'. (FM). The frontline employees also consistently stated that they have never received feedback from the managers about the situations when they have given customers some compensation: 'I have never heard that anyone would have got some critique about how someone has been compensated', (F4).

\subsubsection{Support in service recovery situations}

According to the interviewees, the working environment at the case hotel is good. The frontline employees felt that helping each other and the support of their colleagues while resolving service recovery situations and dealing with an angry customer was very important. The support of a colleague can also be seen as increasing self-confidence, especially in cases when there is a question as to whether someone deserves compensation or not: 'When you have the support of a colleague, even though you both have equally much authority, so when you make the decisions together, you get self-confidence out of it' (F7). One interviewee points out that 'if you are working with a more experienced employee, you get quite good support, but from the less experienced employees you will not necessarily get support' (F5). This is in line with the fact that the employees learn their work by standing beside the more experienced employees.

An interesting point was that a part-time employee felt that making decisions is easier when working alone in a shift because nobody checks whether you act according to the hotel's practices or not. This reflects that even though colleagues support each other, the presence of colleagues can also be viewed as if someone is controlling and assessing what the other is doing. One interviewee indicated that personal characteristics may have an impact on how one perceives working alone: 'It is up to the person how much you trust yourself' (F5). The frontline employees commonly felt that it is easy to get support from the management when needed. The interviewees commented that if they are wondering whether they have been acting correctly in some service recovery situations, they may ask the colleagues or managers for their opinion.

According to the frontline manager, positive feedback from customers is forwarded to frontline employees. On the contrary, the responses of the interviewees reflected that it may not be that easy to give feedback to the colleagues, especially if it would concern something that should be improved. A frontline employee, for instance, felt that she could not teach more experienced employees what to do. Another frontline employee also stated that giving feedback to colleagues is difficult and wonders 'how to present the matter so that it isn't taken in a negative way and is understood that it should be seen as an opportunity and not as criticism' (F6). One interviewee mentioned that it is especially difficult to comment on a colleague's ways of carrying out customer service: 'You can give feedback if it concerns a matter, but it's quite difficult to step in to a colleague's way of serving customers' (F5).

The hotel manager also indicated that he tries to avoid giving employees negative feedback concerning the ways in which a frontline employee has handled service recovery situations: 'If I start talking about it, the employee will be upset and he/she has already made a significant contribution when he/she has resolved the situation and calmed down the customer, so I just swallow it at that point' (HM). On the other hand, one interviewee stated that it would be nice to get some feedback sometimes: 'I have never received either positive or negative feedback. Getting 
feedback would of course be something that would motivate me' (F6). According to another interviewee: 'I guess the work has been done well as no negative feedback has come up' (F7). The previous comments suggest that there may be some difficulties in exchanging constructive feedback between colleagues.

\section{Conclusions and managerial implications}

According to these findings, the lack of instructions makes frontline employees insecure in their decision making and leads to inconsistencies in the resolution of service failures. On the other hand, particularly the experienced frontline employees perceived the absence of clear instructions as a sign of trust and empowerment. Additionally, these findings indicate that not only the work experience but also personality traits seem to have an impact on the perceived need for clear instructions, which is in line with Cook (2002) and Lovelock and Wirtz (2011). Because employees may have different expectations and needs, written instructions would assist and support them in utilizing empowerment, and with no doubt also improve the consistency of the service recovery processes, which is in line with earlier research (Bowen \& Johnston 1999; Huang, 2010).

The findings of this study indicate that the support of colleagues may be even more crucial in coping with service recovery situations and recovering from them than the support of managers, which has been emphasised in earlier studies. These findings imply that seamless teamwork and a good relationship between colleagues are crucial factors in a successful employee recovery. Earlier research suggests that dealing with verbally aggressive customers causes employees, both emotional dissonance and emotional exhaustion (Karatepe et al. 2009), which are also visible in this study. Nevertheless, our findings indicate that the frontline employees regard both the aggrieved customers and service recovery situations as a normal part of their work. They discuss the difficult situations with their colleagues right after they occur, and recover from them relatively fast.

One important finding of this study indicates that personality traits have an influence on how easily employees can cope with service recovery situations and recover from them, which is in line with the findings of Yavas et al. (2010) and Karatepe (2014). A recent study of Karatepe (2014) highlights the concept of hope as an emerging construct in positive organisational behaviour, referring to goal-oriented determination and planning to meet the goals, including both willpower and waypower thinking. Based on his findings, Karatepe (2014) states that 'hopeful frontline employees pursue strategies to reach their goals by feeling energetic and enthusiastic and being happily immersed in their work' (p. 691). Hence, personality traits determine how the frontline employee perceives handling aggrieved customers, how much support is needed in service recovery situations, and finally, how well and fast employee recuperation occurs from the service recovery situations. It is essential that managers discuss with each one of the employees how they wish to use empowerment, and how many instructions they would prefer to have. These topics could be included in the performance appraisal interviews.

Overall, we agree with Johnston and Michel (2008) who state that customer recovery, process recovery, and employee recovery should be considered as an integrated process. Even though it is important to understand the essential factors of each dimension, if a company chooses to focus only on one dimension, the potential benefits of a successful service recovery process will only be achieved partially.

This study examined frontline employees' perceptions at only one hotel and in one geographical area. Hence, the findings cannot be considered to directly fit the frontline employees' perceptions in other case environments. However, for hotels of a similar type, the findings provided can be expected to be transferable.

\section{References}

[1] Black, H. G. \& Kelley, S. W. (2009). A storytelling perspective on online customer reviews reporting service failure and recovery. Journal of Travel \& Tourism Marketing, 26(2), pp. 169-179

[2] Boshoff, C. \& Allen, J. (2000). The influence of selected antecedents on frontline staff's perceptions of service recovery performance. International Journal of Service Industry Management, 11(1), pp. 63-90

[3] Boshoff, C. \& Leong, J. (1998). Empowerment, attribution and apologising as dimensions of service recovery: An experimental study. International Journal of Service Industry Management, 9(1), pp. 24-47

[4] Bowen, D. E. \& Johnston, R. (1999). Internal service recovery: developing a new construct. International Journal of Service Industry Management, 10(2), pp. 118-131

[5] Bradley, G. L. \& Sparks, B. A. (2000). Customer Reactions to Staff Empowerment: Mediators and Moderators. Journal of Applied Social Psychology, 30(5), pp. 991-1012 
[6] Bradley, G. L. \& Sparks, B. A. (2009). Dealing with service failures: the use of explanations. Journal of Travel and Travel and Tourism Marketing, 26(2), pp. 129-143

[7] Chang, H-S. \& Hsiao, H-L. (2008). Examining the casual relationship among service recovery, perceived justice, perceived risk, and customer value in the hotel industry. The Service Industries Journal, 28(4), pp. 513-528

[8] Conger, J. A. \& Kanungo, R. N. (1988). The Empowerment Process: Integrating Theory and Practice. Academy of Management Review, Jul88, 13(3), pp. 471-482

[9] Cook, S. (2002). Customer Care Excellence: How to Create an Effective Customer Focus. Fourth Edition. Kogan Page, London.

[10] Crawford, A. \& Riscinto-Kozub, K. (2010). The Role of the Employee: An Exploratory Study in Service Recovery Satisfaction in the Luxury Resort Industry. Journal of Tourism Insights, 1 (1), Article 4, pp. 35-44

[11] Eriksson, P. \& Kovalainen, A. (2008). Qualitative Methods in Business Research. SAGE Publications, London.

[12] Firnstahl, T. W. (1989). My Employees Are My Service Guarantee: The key to growth and profits is getting employees to give away more of your products and services. Harvard Business Review, July-August, pp. 28-32

[13] Greasley, K., Bryman, A., Dainty, A., Price, A., Naismith, N. \& Soetanto, R. (2008). Understanding empowerment from an employee perspective: What does it mean and do they want it? Team Performance Management, 14(1/2), pp. 39-55

[14] Gruber, T. (2011). I want to believe they really care: How complaining customers want to be treated by frontline employees. Journal of Service Management, 22(1), pp. 85-110

[15] Grönroos, C. 2007. Service Management and Marketing, Customer Management in Service Competition, 3rd edition. Chichester: Wiley

[16] Grönroos, C. (1988). Service quality: the six criteria of good perceived service quality. Review of Business, 9(Winter), pp. 10-13

[17] Huang, W-H. (2010). Other-customer failure: Effects of perceived employee effort and compensation on complainer and non-complainer service evaluations. Journal of Service Management, 21(2), pp. 191-211

[18] Johnston, R. \& Michel, S. (2008). Three outcomes of service recovery: Customer recovery, process recovery and employee recovery. International Journal of Operations \& Production Management, 28(1), pp. 79-99

[19] Karatepe, O. M. (2012). The effects of coworker and perceived organizational support on hotel employee outcomes: the moderating role of job embeddedness. Journal of Hospitality \& Tourism Research, November 2012, 36(4), pp. 495-516

[20] Karatepe, O.M. (2014). Hope, Work Engagement, and Organizationally Valued Performance Outcomes: An Empirical Study in The Hotel Industry. Journal of Hospitality Marketing \& Management, 23(6), pp. 678-698

[21] Karatepe, O. M., Yorganci, I. \& Haktanir, M. (2009). Outcomes of customer verbal aggression among hotel employees. International Journal of Contemporary Hospitality Management, 21(6), pp. 713-733

[22] Kim, T. T., Yoo, J. J-E., Lee, G. \& Kim, J. (2012). Emotional intelligence and emotional labor acting strategies among frontline hotel employees. International Journal of Contemporary Hospitality Management, 24(7), pp. 1029-1046
[23] Komunda, M. \& Osarenkhoe, A. (2012). Remedy or cure for service failure?: Effects of service recovery on customer satisfaction and loyalty. Business Process Management Journal, 18(1), pp. 82-103

[24] Lee, M. J., Singh, N. \& Chan, E. S. W. (2011). Service failures and recovery actions in the hotel industry: A text-mining approach. Journal of Vacation Marketing, 17(3), pp. 197-207

[25] Lovelock, C. \& Wirtz, J. (2011) Services marketing: People, technology, strategy. Seventh Edition, Pearson, Boston.

[26] Maxham III, J. G. (2001). Service recovery's influence on consumer satisfaction, positive word-of-mouth, and purchase intentions. Journal of Business Research, 54(1), pp. 11-24.

[27] McQuilken, L. (2010). The influence of failure severity and employee effort on service recovery in a service guarantee context. Australasian Marketing Journal, 18(4), pp. 214-221

[28] Michel, S., Bowen, D. \& Johnston, R. (2009). Why service recovery fails: Tensions among customer, employee, and process perspectives. Journal of Service Management, 20(3), pp. 253-273

[29] Ohnesorge, D. (2004). Coding: A Challenge for Researchers. In R. Buber, J. Gadner. \& L. Richards (Eds.), Applying Qualitative Methods to Marketing Management Research. New York: Palgrave Macmillan, pp. 123-138

[30] Pelit, E., Öztürk, Y. \& Arslantürk, Y. (2011). The effects of employee empowerment on employee job satisfaction: A study on hotels in Turkey. International Journal of Contemporary Hospitality Management, 23(6), pp. 784-802

[31] Pranic, L. \& Roehl, W. S. (2012). Rethinking service recovery: A customer empowerment (CE) perspective. Journal of Business Economics and Management, 13(2), pp. 242-260

[32] Reichertz, J. (2004). Abduction, Deduction and Induction in Qualitative Research. In U. Flick, E. von Kardorff \& I. Steinke (Eds.), A Companion to Qualitative Research. London: SAGE Publications, pp. 159-164

[33] Ro, H. \& Chen, P-J. (2011). Empowerment in hospitality organizations: Customer orientation and organizational support. International Journal of Hospitality Management, 30(2), pp. 422-428

[34] Roulston, K. (2010). Reflective interviewing: A Guide to Theory \& Practice. London: SAGE Publications

[35] Smith, J.S. \& Karwan, K.R. (2010). Empirical Profiles of Service Recovery Systems: The Maturity Perspective. Journal of Service Research, 13(1), pp. 111-125

[36] Suh, J-H. K., Barker, S., Pegg, S. \& Kandampully, J. (2005). Service Recovery Readiness in Australian Hospitality and Leisure Operations. Journal of Quality Assurance in Hospitality \& Tourism, 6(1-2), pp. 43-64

[37] Swanson, S. R. \& Kelley, S. W. (2001). Service recovery attributions and word-of-mouth intentions. European Journal of Marketing, 35(1), pp. 194-211

[38] Thomas, G. (2011). How to do Your Case Study: A guide for students \& researchers. London: SAGE Publications

[39] Wilson, A., Zeithaml, V., Bitner, M. J. \& Gremler, D. (2008). Services marketing. Integrating customer focus across the firm. London: McGraw- Hill

[40] Yagil, D. (2002). The relationship of customer satisfaction and service workers' perceived control: Examination of three models. International Journal of Service Industry Management, 13(4), pp. 382-398 
[41] Yagil, D. (2009). Self-serving attributions and burnout among service employees. International Journal of Organizational Analysis, 17(4), pp. 320-338

[42] Yavas, U., Karatepe, O. M., Avci, T. \& Tekinkus, M. (2003). Antecedents and outcomes of service recovery performance: an empirical study of frontline employees in Turkish banks. International Journal of Bank Marketing, 21(5), pp. 255-265

[43] Yavas, U., Karatepe, O. M. \& Babakus, E. (2010). Relative efficacy of organizational support and personality traits in predicting service recovery and job performances: a study of frontline employees in Turkey. Tourism Review, 65(3), pp. 70-83

[44] Yoo, J. J-E., Shin, S-Y. \& Yang, I-S. (2006). Key attributes of internal service recovery strategies as perceived by frontline food service employees. Hospitality Management, 25(3), pp. 496-509
Dr Raija Komppula is a Professor of Marketing, especially Tourism Business, at the University of Eastern Finland, Business School. Her research interests include research on tourist experience, customer involvement in new service development in tourism, destination branding, market orientation, small business research and entrepreneurship, cooperation and networks. Her publications include articles in Tourism Management, Journal of Travel and Tourism Marketing, Tourism Review, Journal of Vacation Marketing, Journal of Hospitality and Tourism Management, Journal of Strategic Marketing.

Satu Schumacher completed her Master of Science (Econ.) studies at the University of Eastern Finland Business School and now works in the industry. 